\title{
THE STRUCTURE OF THE FOWL'S ULTIMOBRANCHIAL GLAND
}

\author{
R.-D. HODGES \\ Department of Poultry Research, Wye College (University of London) \\ Near Ashford, Kent (Great-Britain)
}

\section{INTRODUCTION}

It has been suggested that the C cells of the ultimobranchial gland (or ultimobranchial body) of the fowl are the site of origin of the recently-discovered hypocalcæmic hormone calcitonin (HACHMEISTER, KRACHT, KRUSE and LENKE, I967). So far, however, the evidence in favour of this hypothesis has only been circumstantial in nature (HACHMEISTER et al., I967 ; COPP, COCKCROFT and KUEH, I967 $a$ and $b$; Moseley, Mat'Hews, Breed, Galante, Tse and MaC InTyre, ig68) and no direct demonstration of calcitonin within the C cells, such as that performed on the dog thyroid by Bussola'ti and PEARse (I966) using the immunofluorescent technique, has yet been carried out on the fowl ultimobranchial.

The C cells of this gland are only one component of what is histologically a comparatively complex structure and it is the intention of this paper to describe in some detail the structure of the gland which, because of its presumed secretion of calcitonin, is involved in the calcium metabolism of the fowl. This contribution is composed firstly of a review of published work on the embryology, anatomy, histology and ultrastructure of the gland and secondly of an account of personal work on the histology, histochemistry and ultrastructure of the gland. These two sections will, however, be combined to give a single overall account of the structure of the ultimobranchial.

\section{DEVEI,OPMENT}

The 72 hour chick embryo possesses six pharyngeal pouches and from these develop the pharyngeal derivatives. Pouches I and II have no derivatives and rapidly atrophy. Parathyroids III and IV and thymuses III and IV are formed from the third and fourth pouches respectively (VERDUN, I898; DUDLEY, I942; SCHRIER 
and Hamition, I952). The fifth pouch disappears (Johnson, I9I8; DUdLEY, I942) and the sixth pouch gives rise to the ultimobranchial body (RABL, I907; DUDLEY, I942).

On the sixth day of incubation the ultimobranchial body separates from the branchial endoderm (TERNI, I927) and consists of a round body composed of columnar cells surrounding a central cavity (DUDLEY, I942). From the seventh day onwards the ultimobranchial body begins to grow rapidly, epithelial buds pushing out into the surrounding mesenchyme and dividing in such a way that eventually the gland consists of a mass of anastomosing cellular cords interspersed with fine mesenchymal channels in which run blood capillaries (DUDLEY, I942). Until the twelth day the original anlage remains as a dense central core, but thereafter the whole gland becomes more uniform in appearance due to invasion of mesenchymal elements.

The cells of the gland are small and polygonal and are arranged in irregularlyanastomosing cords or small masses. There is no connective tissue capsule enclosing the organ and thus it tends to spread towards and around adjacent organs such as parathyroid IV and the carotid body (DUDIEY, 1942). By the end of the ninth day of incubation the ultimobranchial body has become established in its adult position. On the left side the body lies caudo-dorsal to the base of the common carotid, close to the posterior part of parathyroid IV and to the carotid body. The right ultimobranchial tends to have a position similar to that of the left but lies slightly morecaudal.

In the latter stages of development the organ continues to grow, giving rise to an irregularly-shaped, somewhat elongated gland composed of anastomosing strands and islands of cells compactly set in a fine reticular stroma which contains numerous fine blood vessels. The cavities or vesicles which are a constant feature of the gland throughout the life of the bird first appear during the fifteenth day of incubation (DUDLEY, I942). Parathyroid nodules, which are commonly but not universally found within the gland, are recognizable by the eleventh day of incubation. Even a day or two earlier it may be possible to recognize groups of more darkly-staining cells which are apparently the forerunners of the nodules. The parathyroid cells seem to arise from the parenchyma cells, completely independently of the main parathyroids (DUDLEY, I942).

\section{ANATOMY}

In several recent papers descriptions of the positions of the left and right ultimobranchial bodies in relation to the surrounding organs in the anterior thorax have been somewhat conflicting or lacking in clarity (COPP et al., 1967 $a$ and $b$; MOSELEY et al., Ig68; LUARSEN-JONES, I968). The present description is based upon dissections of about 20 chickens, mainly adult hens but also including a few young ( 6 week old and 5 week old) cockerels. All the birds were of the White Leghorn strain and it is possible that birds of other strains might have slightly different anatomical relationships. However, the present findings are in close agreement with those of MICHELUCCI (I96I) who dissected 24 birds of an unnamed strain. 
Text-figure I shows, in semidiagramatic form, a ventral view of the anterior thoracic cavity of a young cockerel (the anatomical relationships described here are those seen in such a ventral view). The left ultimobranchial body lies in close apposition to the posterior edge of parathyroid IV, normally with the anterior edge of the gland underlying this edge of the parathyroid (MICHELUCCI, I96I). Frequently

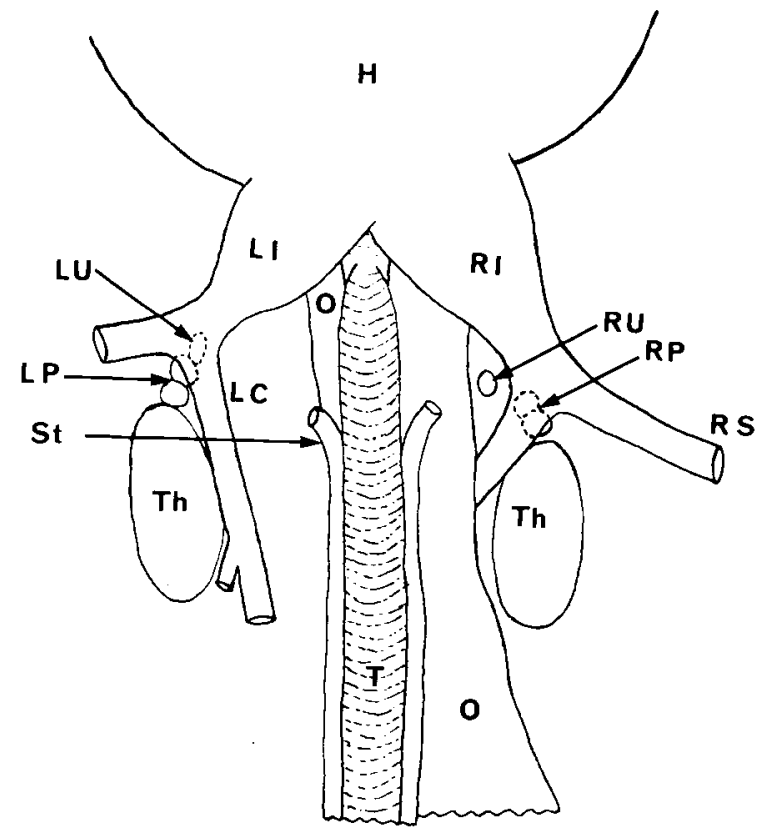

FIG. I. - Semidiagramatic representation of a ventral view of the anterior thorax of a six week old cockerel showing the relationships

of the ultimobranchial glands to the surrounding organs

$\mathrm{H}$ : heart ; LP and RP : left and right parathyroid glands ; RS : right subclavian artery ; LU and RU left and right ultimobranchial glands ; $\mathrm{O}$ : oesophagus ; LC : left common carotid artery ; St : sternotrachealis muscle ; $\mathrm{T}$ : trachea; Th : thyroid gland ; LI and RI : left and right innominate arteries.

at least part of this parathyroid/ultimobranchial complex (parathyroid III — parathyroid IV - ultimobranchial body) is hidden beneath the division of the left innominate artery into the subclavian and common carotid arteries, and thus can best be seen by cutting the subclavian artery at the edge of the thoracic cavity and reflecting it medially. Alternatively this glandular complex may lie adjacent to the common carotid artery, in the angle between it and the subclavian artery. Thus on the left side there is usually a continuous or almost continuous sequence of glands thyroid, parathyroids, ultimobranchial - passing posteriorly. The thyroid, however, may lie slightly more anteriorly than is shown in text-figure $\mathrm{I}$, particularly in the adult, and can be separated from the parathyroids.

The situation on the right side is different to the left, almost invariably the individual glands being separated from each other. The right thyroid may lie more anteriorly than the left and is normally separated from the parathyroids by a gap of 2-6 $\mathrm{mm}$. (Exceptionally it has been found that either thyroid may lie as much as II $\mathrm{mm}$. anteriorly to the parathyroids). The two parathyroids are closely joined toge- 
ther and are normally totally obscured beneath the division of the right innominate artery or the base of the common carotid artery. The ultimobranchial lies posteriorly and medially to the parathyroids being about midway between the latter and the lateral edge of the oesophagus. In text-figure I the right innominate artery has been displaced slightly to the right to show the ultimobranchial.

The left ultimobranchial lies very close to the dorso-medial surface of the left jugular vein; the right gland lies about $2 \mathrm{~mm}$. medially from the right jugular vein. Either gland may lie close to or partially surround the carotid body of its respective side.

The description of DUDLEY (I942), although dealing with the embryo and young chick, is basically the same as the present one (see Development above). On the other hand the descriptions of COPP et al. (I967 a) and MOSELEY et al. (I968) give the impression that the thyroid/parathyroid/ultimobranchial gland series lie in a well-separated line above the anterior end of the innominate artery with a considerable distance

TABLE I

Descriptions of the size and shape of the ultimobranchial body of the fowl as found in the move recent literature

\begin{tabular}{|c|c|c|}
\hline Reference & Size and Shape & Remarks \\
\hline $\begin{array}{l}\text { Moseley et al. (1968) } \ldots \ldots \ldots \ldots \\
\text { Luarsen-J ones }(1968) \ldots \ldots \ldots \ldots \\
\text { Present material } \ldots \ldots \ldots \ldots \ldots\end{array}$ & $\begin{array}{l}\text { Ovoid organs measuring } 1.5 \times 1 \mathrm{~mm} \\
\text { Flattened bodies } 1-2 \mathrm{~mm} \text { in size. } \\
\text { Left body irregularly ovoid, appro- } \\
\text { ximately } 2 \text { mm long. Right body } \\
\text { irregularly lenticular, approxi- } \\
\text { mately } 2-3 \text { mm long. }\end{array}$ & $\begin{array}{l}\text { Greatest dimension is anterio- } \\
\text { posterior axis. } \\
\text { Greatest dimension is anterio- } \\
\text { posterior axis. Right ultimo- } \\
\text { branchial generally larger than } \\
\text { left. } \\
8-12 \text { week old birds. } \\
\text { Right ultimobranchial tends } \\
\text { to be slightly larger than the } \\
\text { left. }\end{array}$ \\
\hline
\end{tabular}

between the ultimobranchial and the bifurcation of the innominate artery $(5-6 \mathrm{~mm}$., MOSELEY et al., I 968). Such an anterior position has not been noted in the present material and has not been described by I)UDiEY (I942) or MICHELUCCI (I96I). However, TERNI (I927) does show one diagram of a young pullet which is very similar to the illustration of COPP et al. (I967a), and TERNi's other illustrations of young birds and embryos do indicate a considerable variation in the position of these glands. It seems probable therefore that, although the ultimobranchial bodies are generally found in the positions described here, considerable anatomical variation can occur, but they are always found posterior to parathyroid IV.

The ultimobranchial glands do not possess a capsule and have a rather diffuse shape. In the freshly-killed bird they have a pink to red colour on account of the well-developed blood supply. The size and shape as described in the literature are given in table I. Although the gland has been described variously as lenticular, ovoid 
or flattened, its tendency towards irregularity must be stressed, particularly in the adult bird where the presence of several large vesicles within the gland may impart considerable irregularity to its shape.

\section{BLOOD AND NERVE SUPPLY}

The blood supply to the ultimobranchial gland is derived from the common carotid artery. A small artery leaves the dorsal surface of the common carotid about midway between its origin and bifurcation. This branch artery may divide to supply the ultimobranchial, carotid body and the parathyroids (Text-figure 2) ; or alterna-

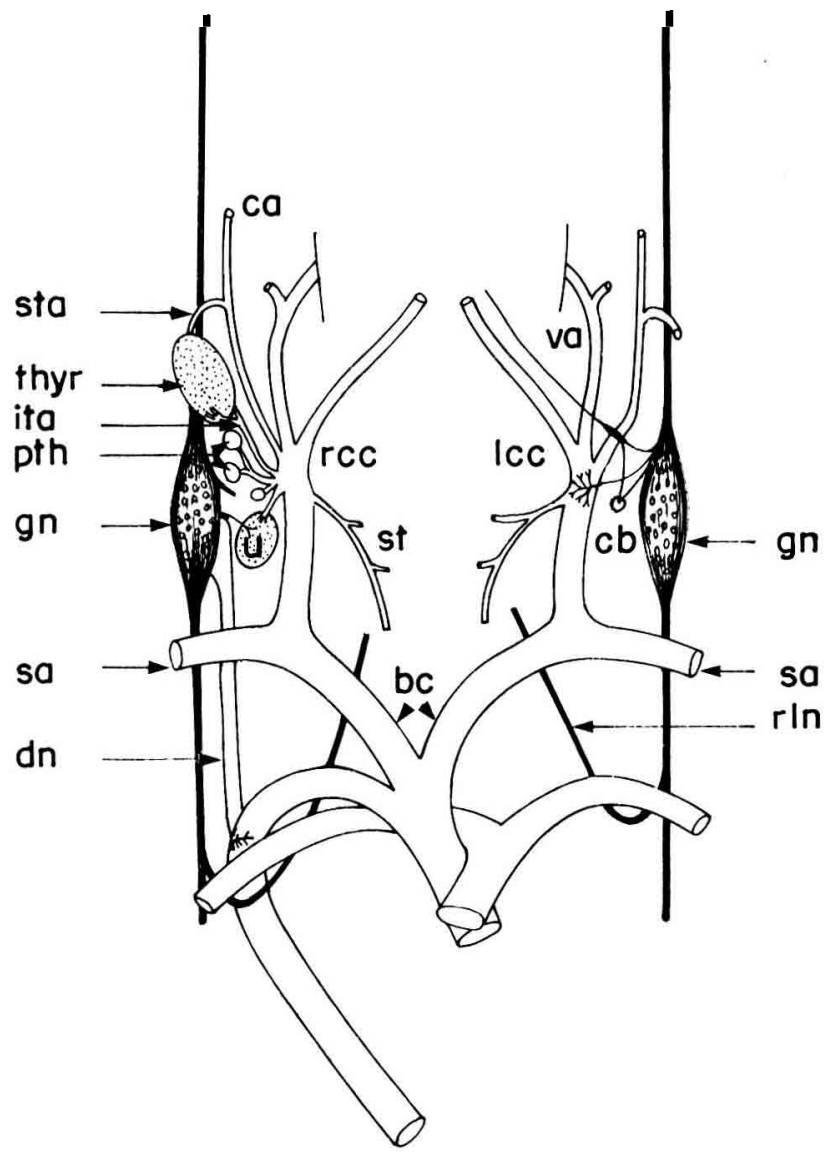

FIG. 2. - Schematic representation of the blood vessels, nerves and glands in the neck and anterior thorax of a bird

This is a composite diagram built up from a number of sources, mostly descriptions of the fowl. bc : brachiocephalic trunks ; $\mathrm{ca}$ : anterior cervical artery ; $\mathrm{cb}$ : carotid body; dn : depressor nerve ; gn : ganglion nodosum of the vagus; ita : inferior thyroid artery; lcc, rcc : left and righ common carotids pth : parathyroids III and IV; rln : recurrent laryngeal nerve; sa : subclavian artery ; st : syringotracheal artery; sta : superior thyroid artery ; thyr : thyroid gland; $\mathrm{u}$ : ultimobranchial body ; va : vertebral artery. (From W. E. A dans, The Comparative Morphology of the Carotid Body and CarotidSinus, I958. Courtesy of Charles C. Thomas, Publisher, Springfield, Illinois). 
tively there may be separate branches of the carotid supplying the parathyroids and the thyroid. The exact situation normally depends upon the separation of the individual glands. As well as supplying the glands a further branch of this artery normally passes posteriorly to the wall of the oesophagus (DUDLEY, I942).

The venous drainage of the ultimobranchial is through a small vein which passes laterally from the gland to enter the medial side of the base of the jugular vein just above its junction with the brachial vein. Branches from the parathyroids and the carotid body may also join this vein.

The nerve supply of the gland is derived mainly from the vagus (Text-figures 2 and 3). The accessory depressor nerve (NonIDEZ, I935) leaves the inner edge of the vagal ganglion nodosum about midway down its length (Text-figure 3 ). This nerve rapidly divides, the depressor nerve itself passing posteriorly to the aortic arch, while the branch supplying the ultimobranchial continues medially and enters the

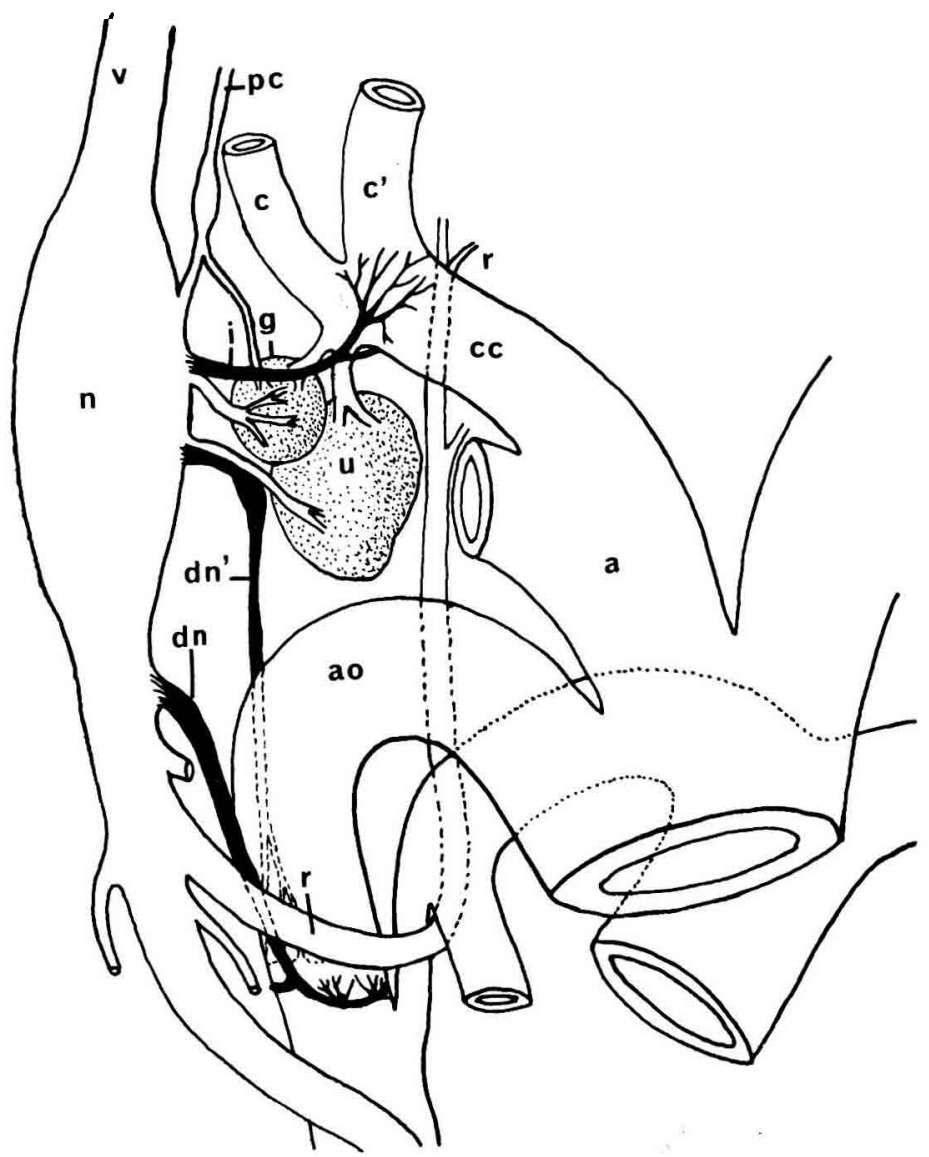

FIG. 3. - Reconstruction of the vascular and nervous anatomy in the region of the great vessels of the heart of a newly-hatched chick (right hand side)

Redrawn from Nonide 2 (I935); with permission. a : innominate artery ; ao : aorta ; cc : common carotid ; c, c': internal and external carotids, respectively; dn ; depressor nerve ; dn' : accessory depressor nerve; $\mathrm{g}$ : glomus caroticum (carotid body); $\mathrm{i}$ : depressor nerve of the carotid ; $\mathbf{n}$ : ganglion nodosum of the vagus ; pc : prevertebral precarotid trunk joining the vagus ; $r$ : recurrent nerve ; $u$ : ultimobranchial body ;v : vagus nerve. 
gland (Nonidez, I935). Smaller nerve bundles also enter the gland from the recurrent nerve and the sympathetic system (DUDI,EY, I942).

\section{HISTOLOGY}

The histology as described here is basically that of a laying hen. Significant differences that are found in immature birds will be described in passing. The structure of the ultimobranchial is fairly complex and for convenience of description the gland can be divided into a number of separate components (see Plate I, fig. I).

\section{The connective tissue stroma}

Although the gland is not enclosed in a capsule the connective tissue stroma is much more dense than the surrounding connective tissue and tends to increase in density as the bird matures. In the newly-hatched chick the stroma is mainly reticular in nature but by 18 days of age definite bundles of collagenous fibres are present forming connecting trabeculae (DUDLEY, 1942) and these gradually increase in size and number. In the mature bird the stroma is composed of a network of numerous bundles of well-developed collagen fibres surrounding the strands, islands etc. of the various epithelial components. The connective tissue is dense, particularly towards the periphery of the gland. Throughout the whole of the stroma run numerous, fine elastic fibres. The area surrounding the gland normally contains large amounts of adipose connective tissue and islands of this may frequently infiltrate the ultimobranchial periphery. Small numbers of mast cells are scattered among the epithelial components throughout the stroma.

\section{The epithelial component}

This can be further subdivided into :

a) The C cells.

The major proportion of the epithelial component is made up of what are presumed to be the $\mathrm{C}$ or calcitonin-producing cells (HAchmeIsTER et al., I967). These cells are frequently arranged in strands and cords (plate $I$, fig. 2), but as it is also possible to recognize many single cells as well as groups of two or three, it is presumed that they have no characteristic grouping. Normally they appear to be scattered throughout the stroma but, partictlarly where compression has been caused by a large vesicle, the cells may be arranged in closely-packed strands. They are of variable shape, round, oval, lanceolate or polygonal. Mitoses of the $\mathrm{C}$ cells are only very infrequently seen.

Many of these cells can be seen to contain large numbers of fine granular bodies and it is possible to recognize what appear to be different stages in a process of production and secretion of these granules. These stages can be described as follows :

(i). Cells with small, rounded, condensed nuclei (approximately $3 \cdot 3 \mu$ in diameter). Cytoplasm basophilic and sparse and arranged closely around the nucleus (total 
diameter approximately $4,7 \mu$ ) (plate I, fig. 3 ). These cells may be at the beginning of a secretory cycle.

(ii). Medium-sized cells (average diameter $6.7 \mu$ ) with medium-sized $(4 \mu)$ round to oval nuclei, chromatin not densely clumped, 2-3 small nucleoli ; cytoplasm slightly basophilic, even, without obvious granules (plate I, fig. 4). These cells may be in the middle of the cycle.

(iii). Large $(9.6 \mu)$ cells containing large $(5 \mu)$ nuclei. Nuclei round, chromatin diffuse, two large nucleoli. Cytoplasm heavily granular. Granules may fill most of the cytoplasm in some cells, in others the circumference of the cell is becoming clear and vacuolated and only the central area remains granular (plate I, fig. 3 and 4). These cells appear to be at the end of the granule formation stage and in the process of secretion.

Normally the majority of cells appear to be in stage 3 with most of the remainder in stage I. Blood capillaries are frequently found running close to or in contact with groups of these cells.

\section{b) The parathyroid nodules.}

As has been described above parathyroid nodules may arise within the ultimobranchial body at about the eleventh day of incubation. According to DUDLEY (I942) although they are common, and as many as three nodules may be found within one gland, not every ultimobranchial contains these structures. In the present material nodules were present in all glands except one case where there was very close contact with parathyroid IV. Each nodule is surrounded by a narrow but definite connective tissue capsule which separates it from the surrounding tissue. In young birds this capsule is well-developed but it tends to become reduced in thickness with maturity (DUDLEY, I942), and in older birds there may not be a strict delimitation of ultimobranchial and parathyroid tissues at some points on the circumference of the nodule. Each nodule is composed of cords of typical parathyroid cells which appear to be normal and active (plate I, fig. I).

Although the parathyroid nodules are generally separated from the ultimobranchial tissue, MICHELUCCI (I96I) has described instances where definite interconnections occur between the two. Occasionally it can be seen that peripheral cords of cells within the parathyroid nodules have insinuated themselves between the fibres of the capsule and entered the ultimobranchial tissue. Once outside the capsule the cords rapidly become modified to form ducts with a central lumen lined by cylindrical cells and the ducts progressively increase in size to form large vesicles or join up with already existing vesicles (MICHELUCCI, I96I). In the present material this description has, in general, been confirmed. However, it has been noted that cords of unmodified parathyroid cells may be found within the ultimobranchial tissue some distance from $\approx$ parathyroid nodule and also that the partially modified cords, consisting of a few $(8-12)$ cuboidal or low columnar cells arranged around a small $(4-6 \mu)$ lumen, may be found close to a group of vesicles when no nodules are apparent, or between the two structures when nodules and vesicles are widely separated. There thus appear to be definite connections, physical and possibly also functional, between the parathyroid nodules and the ultimobranchial vesicles. 


\section{c) The vesicular structures.}

The vesicles first arise at about ${ }_{5}$ days of incubation and are normally found in varying degrees of development in birds of all ages (DUDLEY, I942). During the period of incubation they usually consist of small, round cavities, sometimes separated, sometimes interconnecting and occurring anywhere in the parenchyma. The epithelium may be columnar, cuboidal or squamous and the content of the vesicles is usually granular and/or cellular (DUDLEY, I942). Thus, in general, these structures are very similar to those in more mature birds.

There do not seem to be any significant changes in the vesicular component as young birds grow to maturity and thereafter, except that the vesicles increase in size and number and the surrounding connective tissue becomes more developed. MICHELUCCI (I96I) has stated that the number of vesicles tends to decrease with age (presumably once maturity is passed) but the present material does not support this. Birds as old as those of MrCHELUCCI (27 months) and older nearly always possess numerous, active vesicles. Similarly, DUDLEY (I942) has described the frequent collapse of vesicles in older birds, but again this can not be corroborated. In only two mature specimens have collapsed vesicles been seen ; the remainder being active and distended. DUdLEy's examination of mature birds was confined to 4 hens from $I$ to 3 years old.

The vesicles are very diverse in shape, in dimensions, in structure and in activity. In any one gland there may be a few large vesicles, numerous smaller interconnecting vesicles or a mixture of the sizes (plate I, fig. I). They are normally distended and thus rounded but where there are several closely-packed together the shape may become polygonal (plate I fig. 5). They may be found at any point within the gland. The range of vesicular size is very great. Large vesicles may be up to $500 \mu$ in diameter, with occasional examples exceeding this. MICHELUCCI (I96I) observed a cavity with a maximum diameter of I $200 \mu$. Smaller vesicles have a continuous range of size down to about $20 \mu$, although those of this size and less are almost certainly the enlarged lumina of cellular cords at the point of entering the large vesicles. Although the blood supply to the vesicles is not so well developed as that of the C cells, capillaries can frequently be seen in close association with the vesicular walls.

The epithelium lining the vesicles may be low columnar (simple or stratified) cuboidal or squamous, and the type of lining epithelium does not seem to be related either to the age of the bird or to the volume of the vesicles (MICHEL,UCCI, I96I). As a general rule, however, the epithelium is normally composed of squamous or low cuboidal cells. Only very rarely are any ciliated or mucous cells seen (DUDLEY, I942).

MichelUCCr has functionally divided the epithelial cells into two categories. Firstly the squamous and cuboidal cells which possess a clear, poorly-granular cytoplasm and a small nucleus with scarce chromatin content. Secondly, the columnar cells which have numerous cytoplasmic granules and an irregular free surface. From the present material it does not seem possible to divide cell types in this way. The nuclei of the cells vary considerably in shape from ovoid in the columnar to a thin, flattened disc in the squamous cells. However, in appropriate sections it can be seen that all nuclei have a basically similar structure of a scattered, finely-granular chromatin network, clear nucleoplasm and one or two large nucleoli. The cytoplasm is clear and evenly eosinophilic but normally contains numbers of coarse granules 
which have a moderate or heavy basophilic affinity and the free surface of the cell is irregular and "frayed ", indicating discharge of the granules (plate $I$, fig. 6). The number of granules is very variable, some cells being completely filled with them, but all but the most inactive-looking squamous cells have a basophilic apical edge and signs of granular discharge (plate I, fig. 5). There are also cells to be seen which are usually low columnar or columnar in shape and which have clear, almost hyaline, strongly eosinophilic cytoplasm frequently with a well-differentiated, more palelystaining area around the nucleus (plate 2 , fig. I). These cells may protrude slightly into the lumen and occasionally they may be seen, partially or wholly, to be actually passing out of the epithelium into the lumen (plate 2, fig. 2). Even these cells, however, may show traces of basophilic granules within the cytoplasm.

The stainable content of the vesicles may be of three basic types :

(i). Colloidal. Masses of strongly eosinophilic structureless material which often resembles thyroid colloid. This is not frequently found in the laying fowl but when it is it normally occurs in the small lumina where strands of cells are opening into the vesicles (plate 2 , fig. 3 ). Although this appears to be a separate type of secretion, it may be formed from the breakdown and coalescence of type (ii), as some fixatives do give intermediate appearances between the types. On the other hand the staining affinities of these two secretory types for such stains as Toluidine Blue are rather different.

(ii). Cellular. Numerous large (4-8 $\mu$ diam.), rounded, strongly-eosinophilic bodies which can occur in large masses or in scattered numbers throughout the lumina of all sizes of follicles (plate 2, fig. 2). These frequently appear to have remains of nuclei within them as paler, central areas, or as variably basophilic fragments some of which are Feulgen-positive (plate 2 , fig. I). These cellular bodies appear to be produced within and discharged from the vesicular epithelium either as degenerate cells or as very large masses of cytoplasm (see above). In some of the smaller vesicles these bodies are smaller in size $(2-3 \mu)$ and similarly the small bodies may be found among groups of larger ones, indicating that the process is not necessarily normally one of complete cellular degeneration or desquamation.

(iii). Granular. This consists of masses of coarsely-granular material which fills large areas of the vesicle lumina (plate I, fig. 5). It is normally basophilic although with some fixatives it may sometimes be slightly eosinophilic. It may occur separately or with cellular secretion scattered through it, or it may be found in between and closely applied to the surfaces of accumulations of the large cellular bodies (plate 2, fig. I).

The granular secretion can be seen to be forming within many of the lining cells of the vesicular epithelium.

The vesicular lumen is rarely completely filled by these secretions, the remainder of the space being filled with a serous fluid with little or no staining affinity. MrchE$\mathrm{L}_{4}$ UCCI (I96I) considers that the cellular secretion is composed of desquamated cells, frequently degenerate, and also states that colloidal secretions are only rarely found. DUDLEY (I942) describes secretory substances of similar types to those found here but does consider that colloidal secretions are frequently found. 


\section{The lymphoid component}

Most or all ultimobranchial glands tend to have an area or areas which are infiltrated with lymphoid cells (plate I, fig. I). In the embryo lymphatic infiltration is not extensive, only a few cells being apparent. By ten days of age, however, lymphoid cells may be more abundant in some areas and thereafter infiltration tends to increase with age (DUDLEY, I942). MrCHELUCCI (I96r) considered that the lymphoid tissue occurs more frequently in a peripheral position and this, in general, is so; but foci can be found at any point within the gland. Lymphatic infiltration is of variable density but there are no germinal centres (MrcheluCCI, I96I) and it does not seem to possess the same invasive and destructive nature that is found in the "ectopic 1ymphoid foci " of other organs (LUCAS, I949; LUCAS and OAKBERG, I950). However, no signs of $\mathrm{C}$ cells are to be seen within the more dense foci, indicating that there has been a complete replacement of the original ultimobranchial tissue. Very occasionally some of the areas of lymphoid cells may resemble thymus tissue (DUDLEY, I942; plate I, fig. I).

\section{The eosinophilic component}

Eosinophilic granulocytes arise within the ultimobranchial body at about Io days of incubation. They develop from haemocytoblasts which originate from mesenchyme cells. During the remainder of development eosinophilopoiesis increases considerably until, at hatching, parts of the gland may be almost obscured by these cells (DUDLEY, I942). TERNI (I924) considered that eosinophilopoiesis reaches its height at the nineteenth day of incubation. There is active production of eosinophils in all young birds but the number of cells decreases considerably by one year old (TERNI, I924; DUDLEY, I942). In the present material heavy infiltrations of easinophils were found only in immature birds. At maturity numbers were considerably reduced and in two and a half year old hens only a few scattered cells were seen.

MICHELUCCI (I96I) states that foci of eosinophils were present in all birds examined and that variations in their numbers were seen according to age, season or sex. However, he did not specifically describe these variations.

\section{Blood vessels}

The vascular system of the ultimobranchial is very well developed (plate I, fig. 2), as is to be expected in an endocrine organ. The incoming arterial supply rapidly divides up into small arteries and arterioles and these presumably give rise to normal capillaries. Numerous fine capillaries (4-6 $\mu$ in diameter) can be seen throughout all parts of the gland frequently in close association with strands and groups of the $\mathrm{C}$ cells. However, MicheiUcci (I96I) has referred to the capillaries as being in a sint1soidal form, and numerous small vessels can be seen within the gland, varying in diameter from about $7 \mu$ to $25 \mu$, which have the appearance of sinusoids. Although sinusoidal vessels are often found within endocrine glands, such as the mammalian adrenal and pituitary (BLOOM and FAWCETT, I962), these vessels in the ultimobranchial gland are not regularly in intimate contact with the $\mathrm{C}$ cells and, therefore, unless they can be demonstrated as possessing a true sinusoidal structure, it seems advisable to consider them as large capillaries and venules which lead into the small 
veins draining the different parts of the gland. These latter are found mainly in a peripheral position.

\section{Nerves}

The ultimobranchial is well innervated. Large bundles (about $60 \mu$ in diameter) of myelinated fibres can be seen to enter the gland. These divide up into smaller bundles $(\mathrm{r} 2-20 \mu)$ which spread throughout the gland and the smallest branches of these finally innervate some of the epithelial cells. More will be said about this in the section on ultrastructure. TERNI (I927) found ganglion cells within the left ultimobranchial body only. Such cells have been seen in the present material in one case only. Here they occured in the apical portion of the left ultimobranchial.

\section{HISTOCHEMISTRY}

An analysis of the content of ultimobranchial vesicles in some birds and reptiles by SEHE (1965) has demonstrated the complexity of the secretory material; there being glycogen, mucopolysaccharides (sulphated and neutral), lipids and mucoproteins present.

A similar analysis of the content of the vesicles of the fowl ultimobranchial is given in tables 2 and 3. The secretory content of these vesicles appears to consist mainly of carbohydrate and protein-carbohydrate complexes with very little lipid and phospholipid. It can be concluded from these reactions that both the secretory granules in the vesicular cells and the granular secretion in the lumen are composed of a mixture of glycogen, mucoproteins, neutral mucopolysaccharides and complex acid mucopolysaccharides (not sialomucins or chondroitin sulphates). On the other hand the cellular vesicular secretion does not give a truly positive reaction for any of the above techniques and thus wotld not seem to contain any significant amounts of these substances. Only small amounts of free lipids and little or no phospholipid are found in any part of the vesicles.

The reactions of the $\mathrm{C}$ cells to these histochemical tests have been shown to be almost invariably negative or, at best, only slightly positive. This difference between the secretory granules of the $\mathrm{C}$ cells and the vesicular epithelial cells is to be expected if the former are the precursors of a polypeptide hormone.

Use of the Methyl Green Pyronin and Feulgen-Azure A techniques demonstrates that certain of the $\mathrm{C}$ cells contain a high concentration of RNA. From their size and structure these cells appear to correspond to stages (i) and (ii) in the $C$ cell cycle, i. e. those cells whose cytoplasm is more or less basophilic when stained with routine stains. In general, the vesicular epithelial cells contain little or no detectable RNA.

\section{ULTRASTRUCTURE}

There appears to be only a single published account of the ultrastructure of the fowl's ultimobranchial, that of STOECKEL and PORTE (I967). They examined glands from chicks I-30 days old and described the structure as follows :

The gland is composed of cords of cells separated by vascular-connective tissue 
TABLE 2

Analysis of carbohydrate content of vesicular epithelium and secretion of ultimobranchial gland and comparison with secretory granules of the $C$ cells

\begin{tabular}{|c|c|c|c|}
\hline Technique & $\begin{array}{l}\text { Granular content of } \\
\text { vesicular cells }(a) \text { and } \\
\text { granular secretion }(b)\end{array}$ & Inference & C cells \\
\hline P.A.S. & Both $+++\left(^{*}\right)$ & $\begin{array}{l}\text { Possible presence of } \\
\text { neutral M. P. S. }{ }^{* *} \\
\text { mucoproteins, glyco- } \\
\text { proteins and glycogen. }\end{array}$ & $\begin{array}{l}\text { Very variable, } \\
-1 \pm 1+\end{array}$ \\
\hline P. A. S. / Diastase. & Both + to ++ & $\begin{array}{l}\text { Glycogen present in } \\
(a) \text { and }(b) \text {. }\end{array}$ & $\begin{array}{l}\text { Very variable, } \\
-1 \pm 1+\end{array}$ \\
\hline Best's Carmine. & $\begin{array}{l}\text { Some }+++ \text { granules in }(a) \\
\text { and }(b) \text {. }\end{array}$ & Glycogen present. & 一 \\
\hline $\begin{array}{l}\text { P. A. S. / 2,í Dinitro- } \\
\text { phenyl hydrazine. }\end{array}$ & P. A.S. + to ++ in $(a)$ and $(b)$ & $\begin{array}{l}\text { Some neutral M. P. S. } \\
\text { present in both. }\end{array}$ & - to \pm \\
\hline $\begin{array}{l}\text { Toluidine blue, and } \\
\text { Thionin metachro- } \\
\text { masia, Alcian blue } \\
\text { staining. }\end{array}$ & + to ++ in both $(a)$ and $(b)$ & $\begin{array}{l}\text { Large part of both }(a) \\
\text { and }(b) \text { is composed of } \\
\text { Acid M. P.S. }\end{array}$ & $\begin{array}{c}\text { Metachromasia - } \\
\text { Alcianophilia } \\
- \text { to } \pm\end{array}$ \\
\hline $\begin{array}{l}\text { Toluidine blue meta- } \\
\text { chromasia after sul- } \\
\text { phation. }\end{array}$ & $++\div$ (both) & $\begin{array}{l}\text { Possible presence of } \\
\text { glycogen, neutral } \\
\text { M. P. S., mucopro- } \\
\text { teins and glycopro- } \\
\text { teins. }\end{array}$ & - to \pm \\
\hline $\begin{array}{l}\text { Methylation and } \mathrm{Al}- \\
\text { cian blue. }\end{array}$ & $\begin{array}{l}\text { Both } \pm \text { ( } 2 \text { hr methylation }) \\
\text { Both }-(4 \mathrm{hr} \text { methylation }) .\end{array}$ & $\begin{array}{c}\text { Presence of Acid } \\
\text { M. P. S. }\end{array}$ & - \\
\hline $\begin{array}{l}\text { Methylation/Saponifi- } \\
\text { cation and Alciano- } \\
\text { philia }\end{array}$ & Both - & $\begin{array}{l}\text { Presence of complex } \\
\text { Acid M. P. S. }\end{array}$ & 一 \\
\hline Sialidase/Alcian blue. & Both + to ++ & $\begin{array}{l}\text { Sialic acid-containing } \\
\text { M. P. S. absent. }\end{array}$ & - to \pm \\
\hline $\begin{array}{l}\text { Hyaluronidase/Alcian } \\
\text { blue. }\end{array}$ & t to ++ (both). & $\begin{array}{l}\text { Hyaluronic acid and } \\
\text { Chondroitin sulphates } \\
\text { A and B absent. }\end{array}$ & - to \pm \\
\hline $\begin{array}{l}\text { Bismark Brown stai- } \\
\text { ning. }\end{array}$ & $\begin{array}{l}(a)+\text { to }++ \\
(b)+++\end{array}$ & $\begin{array}{l}\text { Probable presence of } \\
\text { mucoproteins. }\end{array}$ & - \\
\hline
\end{tabular}

$\left(^{*}\right)$ - negative staining reaction, \pm trace reaction, + slight reaction, ++ moderate reaction, +++ intense reaction. ${ }^{* *}$ M. P. S. = Mucopolysaccharides.

The methods and conclusions for this analysis were taken from PeArse (1960), Barka and AnderSon (1963), Thompson (1966), DruRy and Wallington (1967).

TABIE 3

Lipid and phospholipid staining of ultimobranchial tissues

\begin{tabular}{l|l|l|l}
\hline Technique & Vesicle cells and secretions & C cells \\
$\begin{array}{l}\text { Sudan Black B and Sudan III } \\
\text { for free lipids. }\end{array}$ & $\begin{array}{l}\text { A few, scattered, fine fat dro- } \\
\text { plets in the vesicular epithe- } \\
\text { lium and also in the secretion } \\
\text { particularly the cellular se- } \\
\text { cretion. } \\
\text { Very slight reaction in some } \\
\text { Sulphate for Phospholipids. }\end{array}$ & Negative. & $\begin{array}{c}\text { Other tissues } \\
\text { epithelial cells. } \\
\text { Positive reactions in erythro- } \\
\text { cytes, eosinophils, and myelin } \\
\text { sheaths of larger nerve bund- } \\
\text { les. }\end{array}$ \\
\hline$=$
\end{tabular}


layers through which run many nerve fibres. Several types of cells can be found in the cords.

a) Principal cells. These are obviously secretory. The cytoplasm contains numerous, dense, polymorphic granules, maximum size $45^{\circ} \mathrm{m} \mu$, and is rich in ergastoplasmic cysternae and free ribosomes. There is a well-developed Golgi apparatus.

b) Cells characterized by enormous mitochondria, darker hyaloplasm and dilated ergastoplasmic cysternae. The secretory granules are similar to those of the principal cells. These cells are derived from the principal cells.

c) Clear cells. Rare cells devoid of secretory granules but rich in glycogen.

d) Glomic cells. The ultimobranchial cords can be intermingled with those of the carotid body and occasionally some carotid glomic cells can be recognized within the gland. These cells are characterized by their fine secretory granules with a dense core of the catecholamine type.

e) Lining cells. The glandular cells are frequently surrounded basally by the slender cytoplasmic processes of cells devoid of secretory granules but which contain ergastoplasmic sacs with dense inclusions. These are the lining cells.

Nerve axons containing granules with a dense centre enter into a direct contact with the principal cells but no definite synapses have been observed.

In the present material, glands obtained from mature, actively-laying hens, two principal cell types can be recognized. These are found either singly or arranged as cords or small clusters of cells or as small follicles lying among thin strands of well vascularized connective tissue. Other easily recognized cell types associated with the cell cords are fibroblasts, mast cells, macrophages and Schwann cells associated either with myelinated or bundles of unmyelinated fibres.

\section{Type I cells}

'These cells occur either singly, in clusters or in thin cords in close association with capillaries. They are usually ovoid to elongate in shape and are characterized by the presence of numerous dense, membrane-bound cytoplasmic granules.

The nucleus tends to be situated towards one end of the cell, is irregular and usually contains a single nucleolus. The mitochondria are rodlike with their cristae arranged longitudinally. The rough endoplasmic reticulum is not very extensive and is scattered throughout the cytoplasm. Moderately densely-packed free ribosomes and polysomes make up much of the cytoplasmic matrix.

The Golgi complex consists of four or five profiles of smooth-membrane-bounded cysternae and a number of smooth-membraned vesicles. The dense, membrane-bound granules are found scattered throughout the cytoplasm and reach a maximum size of about I-2 $\mu$ in diameter. Smaller, smooth-membraned vesicles containing a material of similar electron density to that of the larger granules are often found in close proximity to the Golgi complex.

Other organelles found in the cells are lysosomal dense bodies, autophagic vacuoles, residual bodies, multivesicular bodies and bundles of tonofilaments.

The type I cells are almost completely ensheathed by thin cytoplasmic extensions of Schwann cells except for areas where axons end in synaptic terminals and other smaller zones where only a basement lamina is present. The basement lamina is continuous with that which lies external to the Schwann cell sheath. 


\section{Type II cells}

These epithelioid cells are usually found in follicular groups. The smaller follicles have a small lumen and in section IO-I2 cells make up their wall. The lumen of the larger follicles can be I00-200 $\mu$ in diameter. The follicular lumina often contain a mucous-like material. The follicles are delimited from surrounding structures by a distinct basal lamina and external to this are found collagen fibres, fibroblasts, myelinated nerve fibres and capillaries. The follicular cells have the shape of truncated pyramids with their bases resting on the basement lamina. In their narrower apices are found numerous, large membrane-bound, electron-opaque granules $\mathrm{I} \mu$ or more in diameter. The matrix of the granules varies in density, those nearer the apex of the cell being the most dense. They have the typical appearance of exocrine secretory granules and presumably discharge their contents into the follicular lumen.

The cells have a smooth basal plasma membrane and their adjacent lateral membranes, separated by a I50-20o $\AA$ gap, run parallel except for occasional interdigitations. Several desmosomes may be found along the lateral cell membranes and associated with the desmosomes are bundles of tonofilaments. The apical surface of the cell is very irregular.

The nuclei are round to ovoid in shape, smooth and contain one or two large nucleoli. The mitochondria are short and rod-like in form, somewhat larger than those of the type I cell, and their cristae are arranged transversely. The rough endoplasmic reticulum consists of long flattened profiles scattered through the cytoplasm particularly at the base and lateral aspects of the cell. Many free ribosomes and polysomes are present.

The Golgi complex in most cells is large and elaborate. It consists of 1ong, curved, closely-arranged profiles of smooth membranes and large numbers of associated smooth Golgi vesicles. The secretory granules vary considerably in electron density. In the less dense granules the matrix consists of minute granules 50-Ioo $\AA$ in diameter. In the larger, denser granules the smaller elements are so tightly packed together they are difficult to distinguish. At the cell apex various stages in granule discharge can be observed.

Other organelles and cell inclusions which can be identified are lysosomal dense bodies, autophagic vacuoles, residual bodies, multivesicular bodies, glycogen granules and lipid droplets.

It is very difficult to make any comparisons between the cell types in the present material and those described by STOECKEI, and PORTE. This is partly due to the fact that their description of the principal cells is not detailed enough to determine which of the present cell types they are describing; it may also be due in part to the fact that their material was from very young chicks and the present material was from mature hens.

\section{DISCUSSION}

All the evidence, histological, histochemical and ultrastructural, indicates that the avian ultimobranchial is an actively secreting gland. If one puts aside the parathyroid nodules there appear to be two main types of secretory cells present, those which have been termed the $\mathrm{C}$ cells and the vesicular epithelial cells. 


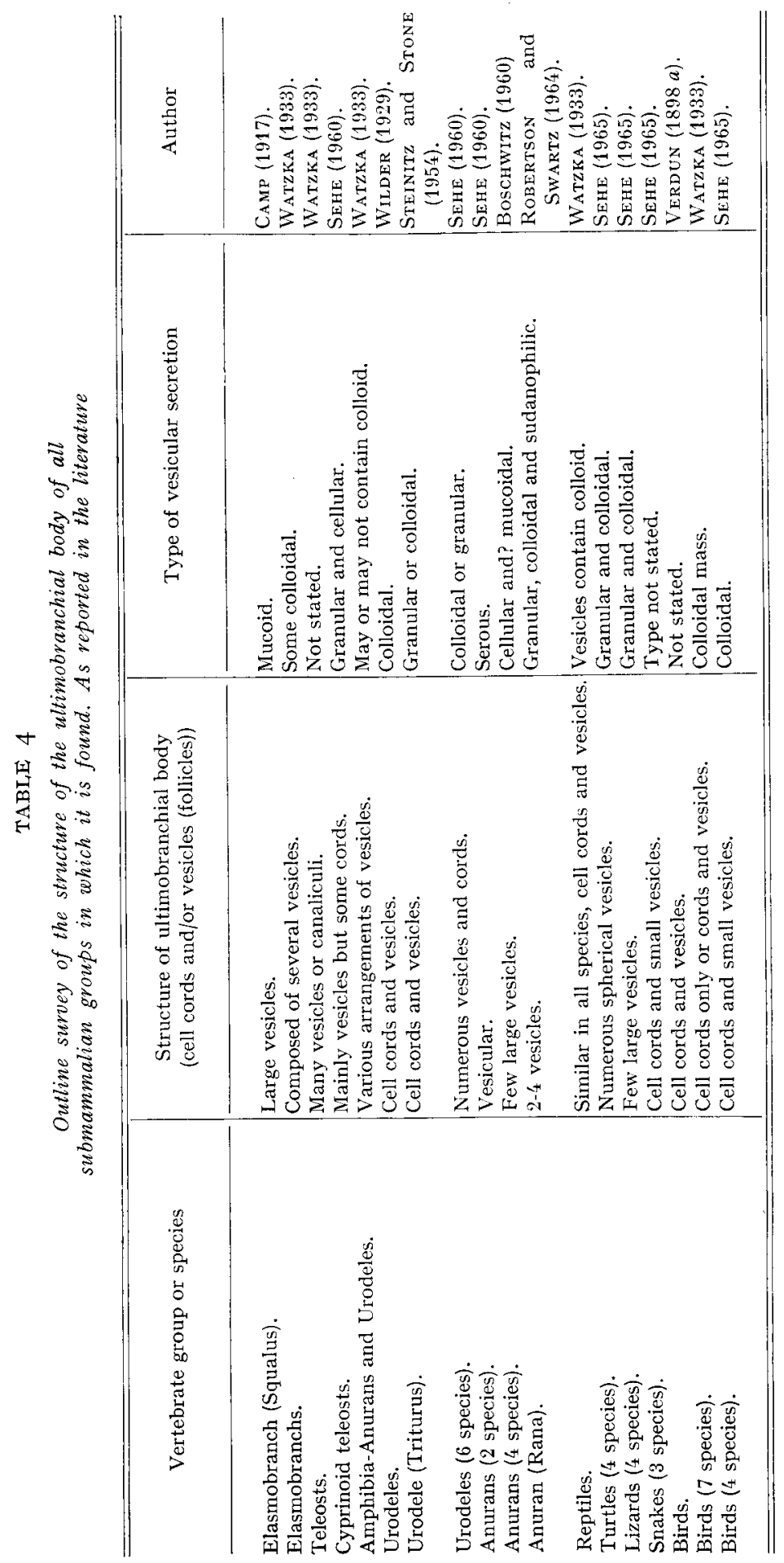


First of all it is necessary to ascertain which of the cell types described in the section on ultrastructure corresponds to the $\mathrm{C}$ cells and which to the vesicular cells. Taking the latter first, it is almost certain that the vesicular cells are the same as the type II cells. Among the common characteristics of these two types are : arrangement of the cells into strands and follicles with a central lumen; presence of numerous large secretory granules, particularly apically, and signs of discharge of these granules into the lumen; irregular apical cell surface; presence of mucous-like material in the lumen; presence of some glycogen granules and lipid droplets in the cytoplasm.

On the other hand it is not so easy to equate the C cells with the type I cells, although they do have some general characteristics in common, e. g. : arrangement of the strands and groups of cells; intimate association of these cells with capillaries; presence of what appears to be a series of stages in the production of granules; secretory granules scattered throughout the cytoplasm.

If, however, one does equate the $C$ cell with the type I cell and the vesicular cell with the type II cell, is there any evidence to indicate which of these cell types produces calcitonin? The vesicular/type II cell is almost certainly not responsible for this function. The histochemistry and ultrastructure indicate a cell producing protein-carbohydrate complexes (not a polypeptide) and secreting them in an exocrine manner into a closed central lumen. In order for the secretion to be liberated into the blood stream it would have to be reabsorbed by the cell and liberated through its basal or lateral cell membrane, since escape direct from the lumen is blocked by apical zonulae occludentes. At the same time the relationship of these cells with underlying capillaries is not very intimate.

Morphologically the $\mathrm{C}$ cell/type I cell is more likely to be the site of calcitonin production. Cell shape, granule size and form etc. are closest to that of mammalian thyroid parafollicular cells. However, the fowl cells are innervated and the thyroid parafollicular cells are not, which suggests that the control mechanism governing granule discharge in birds is different to that in mammals. No direct evidence implicating these cells in the production of calcitonin has been obtained from the present investigations and the question can clearly only be resolved by experimental means.

As the C cell/type I cell seems to be the best candidate for the source of calcitonin, is it possible to ascribe any function to the vesicular/type II cell ? It is possible that these vesicles are merely vestigial structures with little or no function and which secrete mucoid substances because of their pharyngeal origin. On the other hand in all glands a large proportion of these cells are actively secreting their mucoprotein/ mucopolysaccharide granules, and in glands where this activity is very pronounced the vesicles may form up to two thirds of the total glandular volume. If mucous secretion is the only activity ascribed to these cells then it would seem to make the larger proportion of the gland comparatively non-functional. However, much of the vesicular volume is composed of lumen and content and not of active cells as the cells are secreting into a closed lumen, so that the proportion of the gland taken up by this tissue is much less when measured as secreting cells alone. In the thyroid the follicular cells also secrete into a closed lumen and the hormone is later transferred back across the epithelium to the blood stream. If the vesicular secretion has any functional significance such a mechanism would be necessary here.

It does not seem possible at present to determine whether the vesicles have any function or whether they are merely vestigial pharyngeal remnants. This problem 
can only be resolved by experimental means. However, it must be remembered that in nearly all the vertebrates below the mammals the ultimobranchial body is normally composed of both cell cords and vesicles, the proportions of the two structures varying from group to group (see table 4 for a survey of theliterature), and the vesicles contain variable amounts of secretory material. Thus this type of structure is a constant feature of the gland, although those found in lower groups may not be strictly homologous with those of the fowl, and even in mammals, where the ultimobranchial usually fuses with the thyroid during development, well-developed vesicles may be seen in certain species or under special circumstances (WatzKa, I933; VAN DykE, I943, I945; KLAPPER, I95I). Thus the ubiquity of this type of structure should be taken into account when considering whether it is vestigial or functional.

\section{ACKNOWLEDGEMENTS}

The author wishes to express his thanks to Mr. R. P. Gould of the Department of Anatomy, Middlesex Hospital Medical School, with whom he is cooperating in the electron microscope investigations, and to Miss C. FreEman for technical assistance.

\section{NOTE ADDED IN PROOF}

Since this paper was prepared further investigations have shown that the section on ultrastructure is incomplete, in that there is a further major cell type present in the ultimobranchial body. This cell type, which is designated here as Type III, is basically very similar in structure to Type I. The only major ultrastructural differences between these two cell types are that Type III is not surrounded by Schwann cell processes and there are no fine non-myelinated nerve fibres in close relationship to the cell or synaptic terminals ending on the cellular membrane.On the other hand, on the light microscope level, nerve fibres can be traced through to strands of the innervated (Type I) cells from the vagus nerve.

It is now apparent that the Type III cell is by far the most frequently occurring of these two cell types and that the Type I cell comprises only a small proportion of these granulated, epithelioid (C) cells. Type III cells are found in all parts of the ultimobranchial body, whilst Type I cells are found mainly anteriorly or to certain extent throughout the remainder of the gland, generally in a peripheral position.

If, as was suggested in the discussion, these granulated, epithelioid (C) cells are equated with the calcitonin-producing cells of the ultimobranchial body, then it is possible that in the fowl there is a dual mechanism controlling release of calcitonin. Granule discharge from the Type III cell would appear to be controlled by mechanisms similar to that activating mammalian C cells, whilst that from the Type I cell may be under nervous control from the vagus. 


\section{SUMMARY}

I. A review of the current knowledge of the development, anatomy, histology and ultrastructure of the fowl's ultimobranchial gland has been presented. Together with this is included an account of personal work on the histology, histochemistry and ultrastructure of the gland.

2. The ultimobranchial body arises from the sixth branchial pouch and by the sixth day of incubation separates from the branchial endoderm. By the sixteenth day all the main components of the gland have developed and are in recognizable form.

3. In the mature fowl the left gland lies very close to the posterior edge of parathyroid IV, normally underneath the division of the left innominate artery into the subclavian and common carotid arteries. The right gland is separated from the parathyroid and lies midway between parathyroid IV and the lateral edge of the oesophagus.

4. The ultimobranchial gland is composed of several tissues :

a) Cords, strands and group of cells containing palely-staining granules ; these are probably the calcitonin-producing (C) cells.

b) Cords of cells which frequently give rise to large vesicles. These cells contain large, basophilic secretory granules. The secretory product in the vesicles is of three types : granular, cellular and colloidal.

c) Foci of lymphoid cells.

d) Infiltrations of eosinophils.

e) A very well developed blood and nerve supply.

5. The secretory substances in the vesicles are composed of glycogen, mucoproteins, neutral mucopolysaccharides and complex acid mucopolysaccharides. The $\mathrm{C}$ cells show a negative reaction for most of these substances.

6. Ultrastructurally the gland contains two main types of cells. The first type, which appear to be the C cells, are ensheathed by Schwann cells and possess synaptic terminals on their basement membranes. They contain elongated, rod-like mitochondria and numerous membranebound granules. The second type, which are probably the vesicular cells, are not associated with Schwann cells or synapses, and contain short, rod-like mitochondria and numerous apical, membrane-bound granules.

7. The structure of the gland is discussed in relation to the possible functions of the two main types of cells.

\section{RÉSUMÉ}

\section{STRUCTURE DE LA GLANDE ULTIMOBRANCHIALE CHEZ LES OISEAUX DOMESTIQUES}

I. Une revue des connaissances actuelles concernant le développement, l'anatomie, l'histologie et l'ultrastructure de la glande ultimobranchiale de la poule a été présentée. L'auteur y a ajouté un compte rendu de son propre travail sur l'histologie, l'histochimie et l'ultrastructure de la glande.

2. La glande ultimobranchiale naît de la sixième poche branchiale et, au sixième jour d'incubation, elle se sépare de l'endoderme branchial. Au seizième jour toutes les composantes principales de la glande se sont développées et sont facilement reconnaissables.

3. Chez la poule adulte la glande gauche se trouve très près du bord postérieur de la glande parathyroïde IV située sous la division de l'artère innominée gauche en artère sous-clavière et artère carotide commune. La glande droite est séparée de la parathyroïde et se trouve à mi-chemin entre la parathyroïde IV et le bord latéral de l'cesophage.

4. La glande ultimobranchiale se compose de plusieurs tissus :

a) Des cordons, des fils et des groupes de cellules qui contiennent des granules qui se colorent légèrement; ceux-ci sont probablement les cellules (C), qui produisent la calcitonine.

b) Des cordons de cellules qui souvent donnent naissance à de grosses vésicules. Ces cellules 
contiennent de gros granules sécrétoires basophiles. Le produit sécrétoire dans les vésicules est de trois sortes : granulaire, cellulaire et colloïdal.

c) Des foyers de cellules lymphoïdes.

d) Des in filtrations d'éosinophiles.

e) Des nodules parathyroïdiens.

f) Un système de vaisseaux sanguins et de nerfs très bien développé.

5. Les substances sécrétoires dans les vésicules sont composées de glycogène, de mucoprotéines, de mucopolysaccharides neutres et de mucopolysaccharides acides complexes. Les cellules C montrent une réaction négative pour la plupart de ces substances.

6. Du point de vue de l'ultrastructure, la glande contient deux espèces principales de cellules. Celles du premier type, qui semblent identiques aux cellules $C$, sont entourées par des cellules de Schwann et possèdent des terminaisons synaptiques sur leurs membranes basales. Elles contiennent des mitochondries allongées, en forme de baguette et de nombreux granules avec des membranes. Les cellules du deuxième type, qui sont probablement les cellules vésiculaires, ne sont pas associées à des cellules de Schwann ou à des synapses et contiennent des mitochondries bacilliformes et courtes, et de nombreux granules apicaux avec des membranes.

7. La structure de la glande est discutéc en relation avec les fonctions possibles des deux types principaux de cellules.

\section{REFERENCES}

Adams W. L., 1958. The Comparative Morphology of the Carotid Body and Carotid Sinus. Thomas, Springfield, Ill.

Barka T., Anderson P. J., 1963. Histochemistry. Theory, Practice and Bibliographw. Hoeber Medical Division, Harper and Row, New York.

Bloom W., FAwcett D. W., I962. Textbook of Histology. Eighth edition, W. B. Saunders Co., London.

Boschwitz D., I960. The infuence of the hypophysis and the thyroid on the ultimobranchial body of the anura of Israel. J. Embryol. Exp. Morphol., 8, 425-436.

Bussol.ati G., Pearse A. G. E., r967. Immunofluorescent localisation of calcitonin in the Cells of pig and dog thyroid. J. Endocrinol., 37, 205-209.

CAMP W. E., Igr7. The development of the suprapericardial body in Squalus acanthus. J. Morphol. 28, 369-4I 5 .

Copp 1). H., Cockcrofr I). W., Kueh Y., ig67a. Ultimobranchial origin of calcitonin. Hypocalcaemic effect of extracts from chicken glands. Canad. J. Physiol. Pharmacol, 45, Io95-rog9.

Copp D. H., CockCroft D. W., Kueh Y., ig67b. Calcitonin from ultimobranchial glands of dogfish. and chickens. Science, 158, 924-925.

Drury R. A. B., Wallington E. A., I967. Carleton's Histological Technique. 4th. edition. Oxford University Press.

DUDLEY Joséphine, I942. The development of the ultimobranchial body of the fowl, Gallus domesticus Amer, J. Anat, $71,65-89$.

Hachmeister U., Kracht J., Kruse H., Lenke M., I967. Lokalisation von C-Zellen im Ultimobranchialkörper des Haushuhnes. Naturteissenschaften, 54, 6r9.

JoHNSON C. E., I9I8. The origin of the ultimobranchial body and its relation to the fifth pouch in birds J. Morphol., 31, 583-597.

KiAPPER C. E., I95I. The postnatal fate of the ultimobranchial body in the Syrian Hamster. Anat. Rec., 109, 3I2-3I3.

Luarsen-Jones A. P., Ig68. Calcitonin - a new hormone concerned in calcium metabolism. B. $O$. C. M. Quarterly Poultry Bulletin, No. 58, June I968, 3-4.

LuCas A. M., r949. Lymphoid tissue and its relation to so-called normal lymphoid foci and to lymphomatosis. I. Qualitative study of lymphoid areas in the pancreas of chickens. Amer. J. Pathol., 25, II97I2I3.

Lucas A. M., OAKBERG E. F., r950. Lymphoid tissue and its relation to so-called normal lymphoid foci and to lymphomatosis. II. Quantitative analysis of lymphoid areas in the pancreas of laboratory and farm chickens. Amer. J. Pathol., 26, 75-1 Ir.

Michelucci S., I961. Ricerche morfologiche e sperimentali sul corpo ultimobranchiale negli Ucelli (Gallus domesticus). Folia Endocrinologica, 14, 865-883.

Moseley J. M., Matthews E. W., Breed, R. H., Galante L., Tse A., Macintyre I., ig68. The ultimobranchial origin of calcitonin. Lancet, 1, I08-I Io. 
Nonidez J. F., 1935. The presence of depressor nerves in the aorta and carotid of birds. Anat. Rec., 62, 47-73.

Pearse A. G. E., 1960. Histochemistry. Theoretical and Applied. and. edition. Churchill, London.

R ABL H., I907. Uber die anlage der Ultimobranchialen körper bei den Vögeln. Arch. f. mikr. Anat., 70, 1 30-169.

Robertson I). R., Swartz G. F., I964. Observations on the ultimobranchial body in Rana pipiens. Anat. Rec, 148, 2 I9-225.

Serl: C. T., I960. Radioautographic studies on the ultimobranchial body and thyroid gland in vertebrates : fishes and amphibians. Endocrinology, 67, 674-684.

SEHE C. T., I965. Comparative studies on the ultimobranchial body in reptiles and birds. Gen. Comp. Endocrinol., 5, 45-69.

Schrier J. E., HAMILTON H. L., I952. An experimental study of the origin of the parathyroid and thymus glands in the chick. J. Exp. Zool., 119, I65-187.

Steinitz H., Stone: L. S., I954. Observations on the ultimobranchial body of the adult newt Triturus v. viridescens, Anat. Rec., 120, $435-447$.

Sto ckel Marie-Élisabeth., Porte M. A., I967. Sur l'ultrastructure des corps ultimobranchiaux du Poussin. C, R. Acad. Sci., Paris, 265, 2051-2053.

Terni T., 1924. Ricerche sulle eosinofilopoiesie degli Lcelli. Arch. ital. di Anat. e di Embr., 21, 533-56r.

Terni T., I927. Il corpo ultimobranchiale degli Ucelli. Arch. ital. di Anat. e di Embr., 24, 407-53r.

Tuompson S. W., I966. Selected Histochemical and Histopathological Methods, Thomas, Springfield, Ill.

VAN DYKE J. H., I943. The behaviour of the ultimobranchial tissue in the postnatal thyroid gland of sheep. Anat. Rec., 85, 342 .

VAN DrKE J. H., I945. Behaviour of ultimobranchial tissue in the postnatal thyroid gland : Epithelial cysts, their relation to thyroid parenchyma and to "new growths " in the thyroid gland of young sheep Amer. J. Anat., 76, $20 \mathrm{r}-25 \mathrm{I}$.

Virdun P., I898. Quoted by Romanoff A. L., rg6o. The Avian Embryo. The MacMillan Co., New York.

Verdun P., I898 a. Quoted by WiLder, I929.

WatzKa M., I933. Vergleichende Untersuchungen über den ultimobranchialen. Körper Z. mikr.anat. Forsch., 34, 485-533.

WIIDER M. C., I929. The significance of the ultimobranchial body : A comparative study of its occurrence in urodeles. J. Morphol., 47, 283-333. 


\section{PLATE I}

FIG. I

Section through the right ultimobranchial body of a mature hen. Two large vesicles (V) are present and much of the remainder of the gland is honeycombed with unusually large numbers of smaller vesicles. A single parathyroid nodule $(\mathrm{P})$ is situated peripherally and several dense lymphoid foci (L) are also found in a mainly peripheral position. One of these ( $\mathrm{T}$ ) is structurally similar to thymus tissue. The gland is surrounded by adipose tissue. The $\mathrm{C}$ cells are scattered throughout the stroma of the gland. $\mathrm{H}$. and $\mathrm{F}$., $\times$ I8.6.

FIG. 2

Connective tissue stroma of an ultimobranchial gland showing the numerous cords and groups of $C$ cells together with their closely associated capillaries. Also present are many small veins (B), a few nerve bundles $(\mathrm{N})$ and a single vesicle. Mature hen ; Toluidine Blue. $X$ I Io.

\section{FIG. 3}

Ultimobranchial stroma of a mature hen with groups of $C$ cells. Two groups of stage 3 cells (3) can be seen at right and left centre. The cytoplasm of these cells is coarsely grantular and in some there are signs of peripheral vacuolation (? discharge of the granules). Small capillaries (C) are closely associated with these cells and other capillaries $\left(C^{\prime}\right)$ are scattered throughout the stroma. A few stage I cells (I) are grouped at upper centre. Toluidine Blue. $\times 78 \mathrm{I}$.

$$
\text { FIG. } 4
$$

Ultimobranchial stroma showing numerous groups of $C$ cells. A single stage 2 cell (2) lies centrally and two stage 3 cells (3) occur at left and right centre. These latter cells have a clear, almost degranulated cytoplasm. Toluidine Blue. $\times 7^{8 I}$.

FIG. 5

Several medium to small-sized vesicles from the ultimobranchial gland of a mature hen. These structures are lined by squamous or flattened cuboidal cells, many of which (arrows) are actively producing the coarse granular secretion (G) which fills the greater part of the vesicular lumina. Even the less active cells possess a basophilic, "frayed " apical edge, indicating some secretory activity. Numerous $\mathrm{C}$ cells can be seen scattered throughout the stroma and there is slight lymphatic infiltration on the left hand side. H. and E. $\times 379$.

$$
\text { FIG. } 6
$$

Section across the wall separating two ultimobranchial vesicles. The typical squamous lining cells are actively secreting (lower right). The grantular nature of the secretion $(\mathrm{G})$ and the granular ("frayed ") apical edge of the cells can be plainly seen. The stroma of the wall is composed mainly of a collagen fibre network containing a few fibroblasts and flattened C cells. H. and E. $\times 670$. 


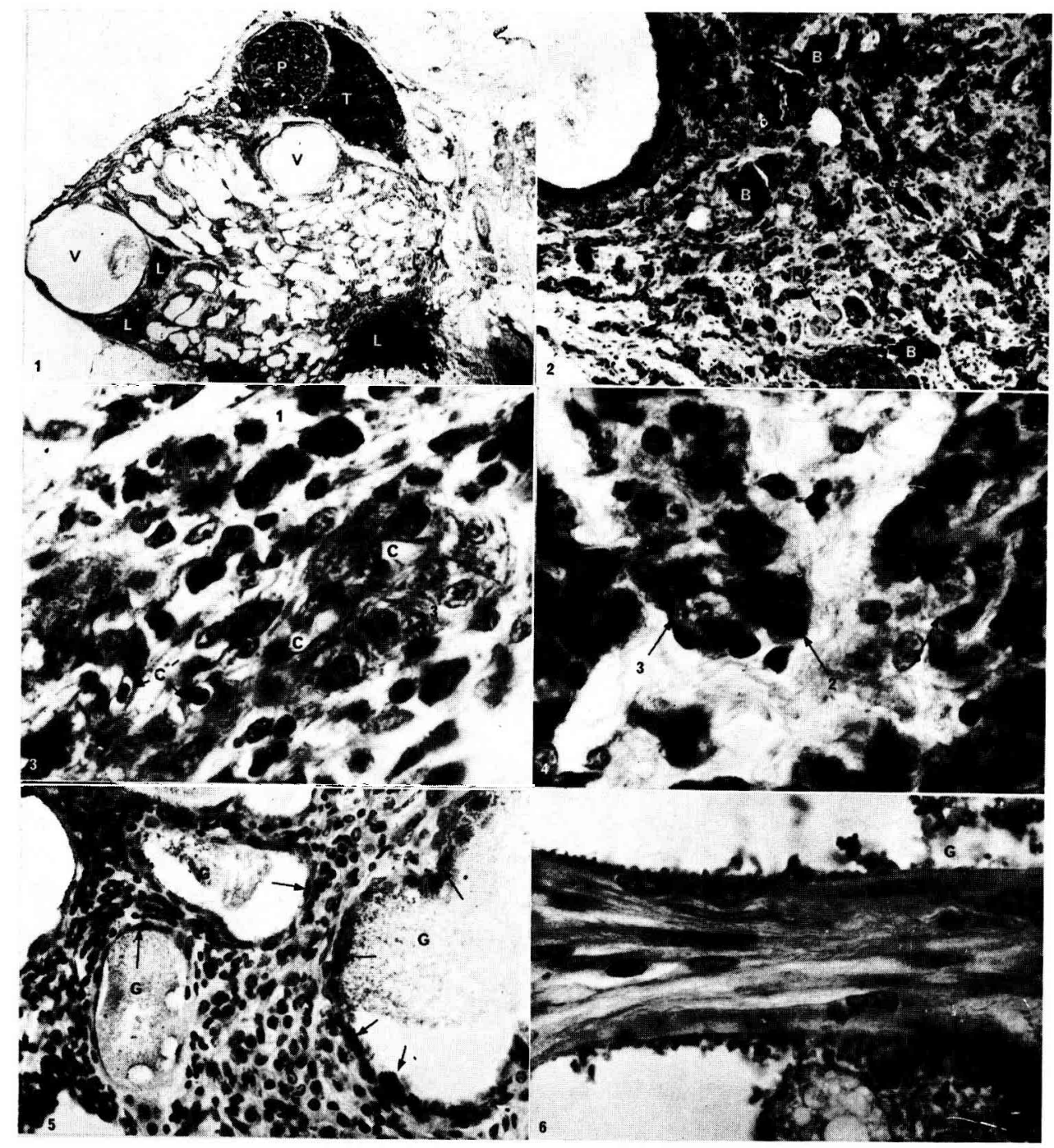

R.-D. HODGES 


\section{PLATE II}

FIG. I

Section of the wall and part of the lumen of an ultimobranchial vesicle which is actively producing both cellular and granular secretions. In two of the cellular bodies (S) degenerating nuclei can be seen, whilst one or two others have inclusions with a more vacuolar appearance. Some of the lining cells have basophilic granules present (arrows) and most of them show signs of secretion at their apical edges. The granular secretion $(G)$ in this section is atypical in that it appears more stranded than homogeneously granular. H. and E. $\times 670$.

FIG. 2

Lower power picture of figure 1 with the vesicle wall peripherally and the lumen and secretion in the centre. Many of the lining cells contain numerous basophilic secretory granules and a few of them (arrows) appear to be undergoing desquamation to form the cellular secretion. H. and E. $\times 326$.

\section{FIG. 3}

Ultimobranchial vesicles, the larger of which appears to be inactive and the smaller of which contains colloidal secretion $(C)$. The latter vesicle is really no more than a cellular strand with an enlarged lumen and may eventually join the larger vesicle. Toluidine Blue. $\times 379$. 


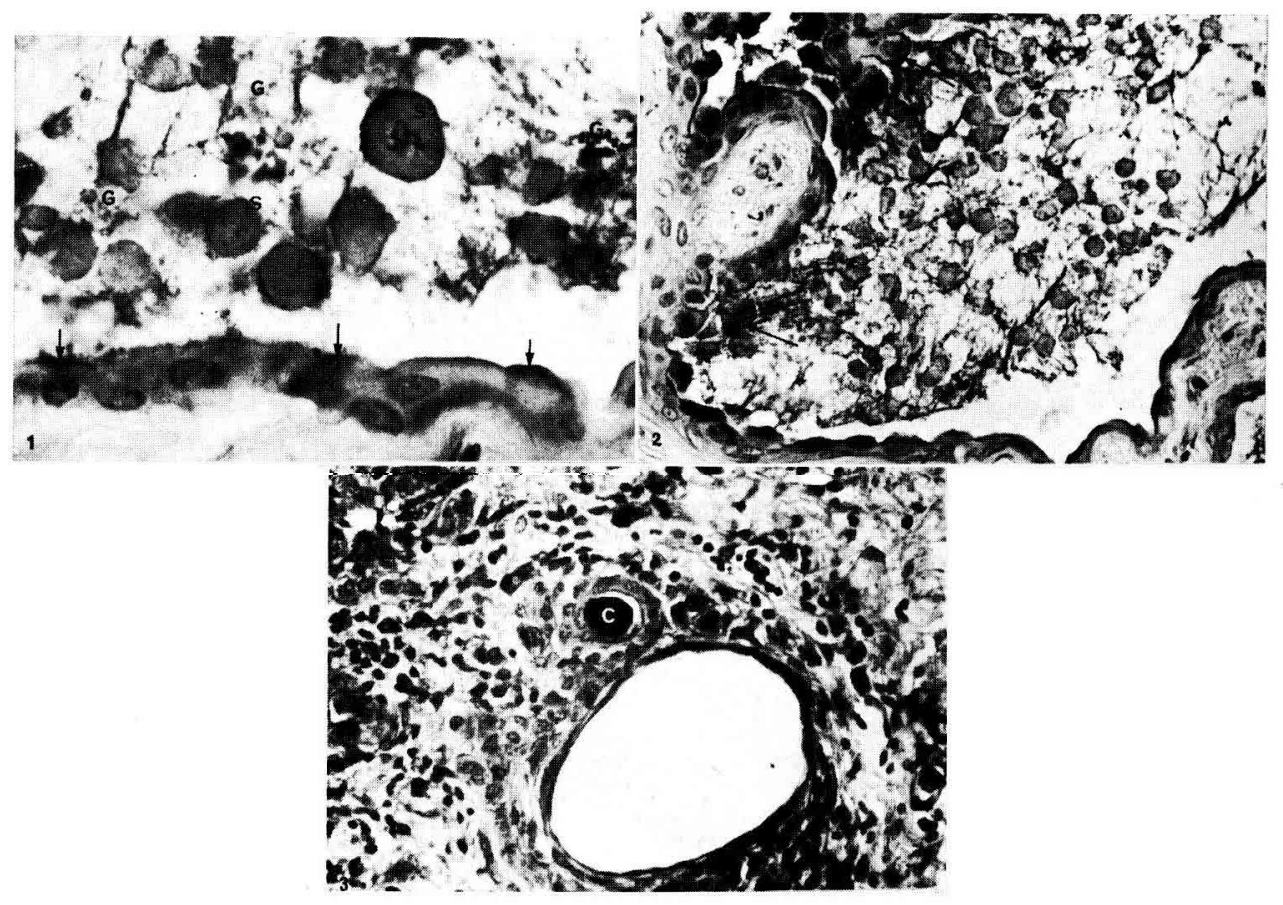

R.-D. HODGES 
Imprimerie Bussière à Saint-Amand (Cher), France. - 7-197o

Dépót légal: 3e trimesire 1970. No d'impression: 124. 

